\title{
Nifedipine and left ventricular function in beta-blocked patients
}

\author{
P I JOSHI, J J DALAL, M S J RUTTLEY, D J SHERIDAN, \\ A H HENDERSON \\ From the Department of Cardiology, Welsh National School of Medicine, Heath Park, Cardiff
}

SUMMARY We studied the acute effects of nifedipine on left ventricular function and haemodynamics at constant heart rate in patients on beta-blocker therapy. Nifedipine significantly depressed left ventricular peak $\mathrm{dP} / \mathrm{dt}$ and peak $\mathrm{dP} / \mathrm{dt} \cdot \mathrm{P}^{\mathbf{- 1}}$. Nifedipine also significantly reduced systemic vascular resistance: this was associated with decreased systolic blood pressure and increased left ventricular stroke output, with slight non-significant increases of ejection fraction and mean circumferential shortening velocity. There was no change in left ventricular end-diastolic pressure. This clinical study shows that nifedipine increases cardiac output in association with arterial dilatation despite evidence for a negative inotropic effect. Such intrinsic negative inotropic effects would normally be masked by compensatory sympathetic activity.

Nifedipine, like other "calcium antagonists", has a negative inotropic effect on isolated heart muscle preparations ${ }^{1}$ and it is also a potent vasodilator of coronary arteries and other vessels. ${ }^{1}$ It is generally claimed, however, that nifedipine has no negative inotropic effect in clinical use, where it is advocated for its vasodilator properties. ${ }^{2}$ Clinical studies, generally not performed at constant heart rate, have been reported as showing, for example, increased left ventricular peak $\mathrm{dP} / \mathrm{dt}$ and peak $\mathrm{dP} / \mathrm{dt} \cdot \mathbf{P}^{-1}$, stroke volume, ejection fraction, mean circumferential shortening velocity, and corresponding changes in systolic time intervals. ${ }^{3-6}$ In the present study we examined the possibility that this apparent discrepancy between clinical and experimental evidence might be the result of compensatory sympathetic activity masking an intrinsic negative inotropic action of the drug.

\section{Methods}

Twelve patients (nine men, age $47 \pm 3$ years; three women, age $55 \pm 2$ years) undergoing cardiac catheterisation for investigation of chest pain were selected for study after obtaining informed consent. Patients with congestive cardiac failure, conduction abnormalities, or valvular heart disease were excluded. Eight of the patients studied were subsequently shown to have coronary artery disease but no regional or general impairment of left ventricular

Received for publication 20 October 1980 function and no other cardiovascular abnormality: four had no abnormal cardiovascular findings. None showed evidence of ischaemia during the study.

All drugs except beta-blockers were stopped for at least 48 hours before the study and all patients received atenolol (100 mg orally 6 hourly) during the 24 hours before the study, with diazepam (10 mg orally) as premedication. Percutaneous catheterisation was carried out from the femoral artery and vein. Systemic pressures were recorded using catheter tip transducers. Mean arterial pressure was obtained by electronic integration of the aortic pressure signal. Left ventricular pressure signals were processed using analogue circuitry (Siemens) to derive $\mathrm{dP} / \mathrm{dt}$ and $\mathrm{dP} / \mathrm{dtP}^{-1}$, recorded at fast paper speed, averaged over 20 beats and thus at least over two respiratory cycles for each measurement. Cardiac output was measured by dye dilution, each result being given as the mean of three estimations. Left ventricular angiography was performed in the right anterior oblique projection. Right atrial pacing at a rate of 100 beats per minute was instituted during all pressure recordings, during cardiac output estimations, and during left ventricular angiography.

Thirty or more minutes after recording haemodynamic measurements and performing left ventricular angiography (when haemodynamic measurements confirmed full recovery from the haemodynamic effects of contrast material) $10 \mathrm{mg}$ nifedipine was given sublingually. Haemodynamic measurements 
Table Effects of nifedipine on haemodynamics and left ventricular function

\begin{tabular}{|c|c|c|c|c|c|c|c|c|}
\hline \multirow[b]{2}{*}{ LVP } & \multirow[b]{2}{*}{ Systolic } & \multirow[b]{2}{*}{$(\mathrm{mmHg})$} & \multicolumn{2}{|c|}{ Control } & \multicolumn{2}{|c|}{ Nifedipine } & $\Delta \%$ & $<0.05$ \\
\hline & & & $\begin{array}{r}141.8 \\
9.5\end{array}$ & $\begin{array}{ll} \pm & 6.4 \\
\pm & 1.7\end{array}$ & $\begin{array}{r}129.6 \\
9.9\end{array}$ & $\begin{array}{l} \pm \quad 8.3 \\
\pm \quad 1.7\end{array}$ & $\begin{array}{r}-9 \\
+4\end{array}$ & $\begin{array}{c}<0.05 \\
\text { NS }\end{array}$ \\
\hline \multirow{3}{*}{ Aortic } & Systolic & $(\mathrm{mmHg})$ & $141 \cdot 8=$ & $6 \cdot 8$ & $128 \cdot 1=$ & $8 \cdot 2$ & -10 & $<0.02$ \\
\hline & Diastolic & (mmHg) & 84.8 & $2 \cdot 9$ & $79 \cdot 5$ & 3.9 & -6 & NS \\
\hline & Mean & $(\mathrm{mmHg})$ & $108 \cdot 8$ & $4 \cdot 7$ & $98 \cdot 1=$ & $5 \cdot 3$ & -10 & $<0.01$ \\
\hline \multirow{2}{*}{\multicolumn{2}{|c|}{ RAP Mean }} & $(\mathrm{mmHg})$ & $0.5=$ & 0.7 & $0.6=$ & 0.7 & +20 & NS \\
\hline & & $\left(1 / \mathrm{min}\right.$ per $\left.\mathrm{m}^{2}\right)$ & $4 \cdot 2$ & \pm 0.3 & $4 \cdot 7$ & \pm 0.3 & +12 & $<0.01$ \\
\hline Peak dP & $\mathrm{P} / \mathrm{dt}$ & $(\mathrm{mmHg} / \mathrm{s})$ & 1579 & \pm 109 & 1457 & \pm 105 & -8 & $<0.01$ \\
\hline Peak dP & $\mathrm{P} / \mathrm{dt} \cdot \mathrm{P}^{-1}$ & (per s) & $18 \cdot 3=$ & $\pm \quad 2 \cdot 6$ & $16 \cdot 7$ & $\pm \quad 2.5$ & -9 & $<0.02$ \\
\hline EF & & & $0.61=$ & \pm 0.02 & 0.64 & 0.05 & +5 & NS \\
\hline Mean V & $\mathrm{JCF}$ & $(\operatorname{circ} / s)$ & $1 \cdot 36=$ & \pm 0.02 & $1 \cdot 48$ & $0 \cdot 14$ & +9 & NS \\
\hline
\end{tabular}

Results are given as mean $\pm \mathrm{SE}$ of mean.

LVP, left ventricular pressure; RAP, right atrial pressure; SVR, systemic vascular resistance; EF, ejection fraction; VCF, ventricular (left) circumferential fibre shortening velocity.

and left ventricular angiography were repeated 20 minutes later. Venous blood samples were obtained for assay of plasma nifedipine levels 10 and 30 minutes after treatment. Coronary arteriography was then performed on each patient.

Volumetric analysis of left ventricular angiograms was performed ${ }^{7}$ and mean velocity of circumferential fibre shortening ${ }^{8}$ was calculated. Data before and after treatment are given as the mean \pm standard error and compared by paired $t$ test, $\mathrm{p}<0.05$ being considered statistically significant.

\section{Results}

Haemodynamic effects of nifedipine are summarised in the Table. Left ventricular systolic pressure and systolic arterial pressure were reduced by nifedipine, as was systemic vascular resistance. Systemic vascular resistance was reduced by 20 per cent, whereas arterial pressure fell by only 10 per cent, in association with a 13 per cent increase in cardiac output. Left ventricular end-diastolic pressure was unaltered. Slight increases in left ventricular ejection fraction and mean circumferential shortening velocity were observed, attributable to the reduction in load implied by the lower systolic pressures. Left ventricular peak $\mathrm{dP} / \mathrm{dt}$ and peak $\mathrm{dP} / \mathrm{dt} \cdot \mathrm{P}^{-1}$ were both significantly depressed by nifedipine. Plasma levels of nifedipine were $42 \cdot 7 \pm$ $8.7 \mu \mathrm{g} / \mathrm{l}$ at 10 minutes and $92.5 \pm 14.3 \mu \mathrm{g} / \mathrm{l}(\mathrm{p}<0.05)$ at 30 minutes after treatment.

\section{Discussion}

The significant and parallel reductions in peak $\mathrm{dP} / \mathrm{dt}$ and peak $\mathrm{dP} / \mathrm{dt} \cdot \mathrm{P}^{-1}$ induced by nifedipine in this group of patients together indicate a negative inotropic effect. ${ }^{910}$ Despite this, the reduction in systemic arterial resistance was associated with an increase in cardiac output, ejection fraction, and mean circumferential shortening velocity. The clinical evidence for a negative inotropic effect accords with the findings in isolated heart muscle experiments, but it differs from previously reported clinical studies, many of which noted even an apparent increase in contractility..$^{3-6}$ We attribute the discrepancy to the compensatory increase in sympathetic activity which normally occurs in response to vasodilatation.

An intrinsic negative inotropic action of nifedipine at therapeutic plasma levels may become apparent clinically during beta-blocker treatment, or possibly in congestive heart failure where sympathetic mechanisms are impaired. ${ }^{11} 12$ These are potentially important considerations in the clinical use of nifedipine. Nevertheless it should also be noted that a negative inotropic effect is not inconsistent with an increase in cardiac output as a consequence of the vasodilatation of peripheral arteries, where there is no associated outflow tract obstruction.

The present study also illustrates the general point that it may be necessary to block compensatory mechanisms in order to demonstrate an intrinsic negative inotropic action of a pharmacological drug in vivo.

\section{References}

1 Fleckenstein A. On the basic pharmacological mechanism of nifedipine and its relations to therapeutic efficacy. In: Domingos A, Lichtlen PR, eds. Third international Adalat symposium. Amsterdam \& Oxford: Excerpta Medica, 1975; 1-13.

2 Camerini F, Angelino PF, Bobba P, Caturelli G, Cherchi A, Maggi GC. Nifedipine in angina pectoris -a multicentre clinical trial. In: Hashimoto $K$, Kimura E, Kobayshi $\mathrm{T}$, eds. First international nifedipine "Adalat" symposium, New therapy of ischaemic heart disease. Tokyo: University of Tokyo Press, 1965: 260-7. 
3 d'Oliveira J, Ruiz Calderow N, Garcilazo E, Patricio J, Tewreyro E. Haemodynamic changes after a single dose of nifedipine (Adalat). In: Domingos A, Lichtlen PR, eds. Third international Adalat symposium. Amsterdam \& Oxford: Excerpta Medica, 1975: 50-4.

4 Van den Brand $M$, Remine WJ, Meester GT, Tiggerlaar-de Widt I, de Ruiter R, Hugenholtz PG. Changes in left and right ventricular haemodynamics in angina pectoris patients following Adalat administration. In: Domingos A, Lichtlen PR, eds. Third international Adalat symposium. Amsterdam \& Oxford: Excerpta Medica, 1975: 69-75.

5 Peigas L, Paes Neto F, Konstadinidis T, de Megalhaes HM, de Souza JEMR, Jatene AD. Haemodynamic evaluation of a new antianginal drug: nifedipine. In: Domingos A, Lichtlen PR, eds. Third international Adalat symposium. Amsterdam \& Oxford: Excerpta Medica, 1975: 76-82.

6 Lydtin H, Lohmoller G, Lohmoller R, Schmitz H, Walter I. Comparative haemodynamic studies with Adalat and other antianginal drugs. In: Domingos A, Lichtlen PR, eds. Third international Adalat symposium. Amsterdam \& Oxford: Excepta Medica, 1975: 98-106.

7 Kasser IS, Kennedy JW. Measurement of left ventricular volumes in man by single-plane cineangiocardiography. Invest Radiol 1969: 4: 83-90.

8 Karliner JS, Gault JH, Eckberg D, Mullins CB, Ross J. Mean velocity of fiber shortening. A simplified measure of left ventricular myocardial contractility. Circulation 1971; 44: 323-33.

9 Noble MIM, Stubbs J, Trenchard D, Else W, Eisele $\mathrm{JH}$, Guz A. Left ventricular performance in the conscious dog with chronically denervated heart. Cardiovasc Res 1972; 6: 457-77.

10 Nejad NS, Klein MD, Mirsky I, Lown B. Assessment of myocardial contractility from ventricular pressure recordings. Cardiovasc Res 1971; 5: 15-23.

11 Chidsey CA, Braunwald E, Morrow AG. Catecholamine excretion and cardiac stores of norepinephrine in congestive heart failure. $\mathrm{Am} \mathcal{f} \mathrm{Med} 1965$; 39: 442-51.

12 Chidsey CA, Sonnenblick EH, Morrow AG, Braunwald E. Norepinephrine stores and contractile force of papillary muscle from the failing human heart. Circulation 1966; 33: 43-51.

Requests for reprints to Dr D J Sheridan, Department of Cardiology, Welsh National School of Medicine, Heath Park, Cardiff CF4 4XN. 